\title{
MĄDROŚĆ JAKO ROZUMIENIE ŚWIATA
}

\begin{abstract}
Zarys treści Artykuł prezentuje refleksje autorskie poświęcone debatom, które miały miejsce podczas prowadzonego seminarium magisterskiego dla studentów. Istotą było poszukiwanie odpowiedzi na pytania: Czym jest mądrość? Gdzie należy jej poszukiwać? Co można uznać za miarę mądrości? Rozważania obejmują wprowadzenie teoretyczne, charakterystykę kontekstów mądrości (poznawania, rozumienia darowania i wydarzania) oraz podsumowanie.
\end{abstract}

Słowa kluczowe Mądrość, prawda, wiedza, metafizyka.

Jestem przechodniem, mąrosśc bywa moim zamyśleniem.

\section{Wprowadzenie}

Podstawową inspiracją podjęcia namysłu nad istotą mądrości była konkretna rzeczywistość. Zwyczajna codzienność akademicka potrafi zadziwić. W powszednich, rutynowych sytuacjach znajduje swój początek wiele intrygujących dróg myślenia. Zdarzenie dydaktyczne jakim jest każde seminarium magisterskie może pobudzić wyobraźnię i skłonić do zastanawiania się. Nie budzi większych wątpliwości konstatacja, że po napisaniu pracy magisterskiej student powinien być mądrzejszy niż przed jej rozpoczęciem. Przyjmując jako prawdopodobne sformułowane stwierdzenie, napotyka się pierwsze, proste pytanie - jaki jest zakres tego stawania się mądrzejszym? W dalszej kolejności dostrzeżemy drugie pytanie - czym jest mądrość (po)jawiająca się podczas zajęć seminaryjnych?

Mądrość pojawia się podczas seminarium z prostej przyczyny. Otóż promotor jest zobowiązany do mądrego prowadzenia zajęć. Ma on obowiązek sensownie kształcić magistrantów. Wówczas mądrość staje się niezbędna do budowania przestrzeni twórczych spotkań. Ale zauważyć można jeszcze jeden aspekt uszlachetniania mądrością seminarzystów. Mądrość jawi się podczas zajęć. Czyli nie 
prowadzi tylko do efektywnego opanowania warsztatu naukowego, ale odsłania to co skrywa się przed wzrokiem dociekliwego badacza. Mądrość jawi się w momentach refleksji heurystycznej, kiedy realność empiryczna nie wystarcza do wyjaśnienia analizowanej rzeczywistości. Osiągnięcie pewności poznawczej bywa czasami początkiem, nie zaś zakończeniem drogi badawczej magistranta - „Ilekroć poszukując prawdy, umysł ludzki poszukiwał niepowątpiewalnego i pewnego punktu wyjścia, wówczas napotykał coś nam nierozdzielnie bliskiego: fak t n a s z e go w $ł$ a s n e go i s t n i e n i a" (Stein 1995: 67). W takich okolicznościach zaniepokojenia epistemologicznego mądrość jawi swoją istotność. Odsłania drogę do pewności innej niż osiągana na zajęciach wiarygodność empiryczna.

Prezentowany artykuł powstał na podstawie notatek dydaktycznych. Są one dwojakiego rodzaju. Mają format materiałów użytecznych do realizowania kolejnych etapów seminarium magisterskiego. Pozwalają osiągnąć zakładane w programie cele kształcenia. Wśród nich odnaleźć można swobodne zapiski na marginesach. Pozwalają one uchwycić twórcze napięcie, ową chwilę zaciekawienia i niepewności otwartego na świat podmiotu. Notatki w tej formie nie są uporządkowane, mają raczej przypadkowy charakter. Na ich podstawie przygotowano przedstawiane rozważania. Nie są one precyzyjnym postępowaniem analitycznym. Ukazują drogę myślenia przebywaną podczas seminarium i wiodącą w stronę mądrości. Praca dydaktyczna nie jest tylko nauczaniem warsztatu analitycznego. Niebagatelne znaczenie mają także poglądy etyczne prezentowane przez nauczyciela akademickiego.

W pracy dydaktycznej opanowanie metod badawczych i kształtowanie postaw moralnych musi iść $\mathrm{w}$ parze. Ich rozdzielanie trzeba traktować jako poważne uchybienie dydaktyczne. Bowiem istota prawdy skrywa się w myśleniu i działaniu, traktowanymi nierozdzielnie. Dlatego też - mądrość bez uczynków jest martwa, a działania pozbawione mądrości są puste.

Punktem wyjścia prowadzonych rozważań stały się trzy problemy:

- Czym jest mądrość?

- Gdzie skrywa się mądrość?

- Co jest miarą mądrości?

W poszukiwaniu odpowiedzi na postawione pytania uwzględniono różnorodne konteksty przebywanej drogi myślenia. Kolejne etapy rozważań składają się z kontekstu poznawania, rozumienia, darowania, wydarzania.

\section{Kontekst poznawania}

Uniwersytet jest wspólnotą mistrzów i uczniów razem poszukujących prawdy. Ta cecha wyróżniała i powinna niezmiennie charakteryzować uniwersytety. Zadziwienie światem i pragnienie wyjaśnienia interesujących zjawisk nieodmiennie towarzyszy ludziom zmierzającym ku źródłom prawdy. We wprowadzeniu 
do przewodnika dydaktycznego dla magistrantów zapisano następującą obietnicę - „Proponujemy wspólne wkroczenie w obszar niepewności poznawczej, aby w efekcie rozpoczętej pracy osiągnąć pewność badawczą. Paradoksalnie, źródłem prawdy jest brak wiedzy w określonej dziedzinie" (Kaczmarek 2012: 5). Nie warto odkrywać już znanych lądów. Być może, z punktu widzenia magistranta, taki sposób postępowania byłby wygodny, ale nie rozwijający umiejętności badawczych. Odkrywanie prawdy rozpoczyna się zatem od wskazania obszarów nieznanych, intrygujących swą zagadkowością. Aby dojrzeć zakres niewiedzy o rzeczywistości konieczne jest spełnienie kluczowego warunku. W drodze ku prawdzie potrzebne jest myślenie. Przedstawiona idea nie zawsze bywa oczywista. W dramacie „Kaligula” Albert Camus skonstruował niebanalny dialog (akt I, scena IV):

„Kaligula: Myślisz, że jestem szalony?

Helikon: Wiesz dobrze, że ja nigdy nie myślę. Jestem na to zbyt mądry".

Postawa mądrości Helikona wyklucza myślenie. W rzeczywistości sytuacja wygląda inaczej. Udzielona odpowiedź została jednak przemyślana. Odrzucenie myślenia wymagało wcześniejszego (prze)myślenia. W czasach zamętu i pomieszania wartości bezmyślność bywa jednak regułą myślową. Myślę, aby nie myśleć. Warunki w jakich przychodzi nam żyć determinują powstawanie paradoksalnego bezmyślnego myślenia. Powyższe rozważania pozwalają sformułować stwierdzenie: Myśle n i e otwi er a drogę ku prawdzi e.

Poszukiwanie prawdy prowadzi do mądrości. Zatem pojawiają się przesłanki do sformułowania: P o d s t a w ą mą droś c i j e s t p r a w d a. Podczas seminarium magisterskiego studentom potrzebna jest w głównej mierze prawda ujmowana klasycznie. Według św. Tomasza z Akwinu - „(...) veritas est adaequatio rei et intellectus", czyli prawda jest zgodnością umysłu z rzeczywistością (cz. I, zag. 16, art. 2). Sformułowanie tej zgodności oraz jej weryfikacja umożliwiają poznawanie prawdy. W pracach magisterskich formułowane sądy mają postać weryfikowalną empirycznie. Zatem zgodność rzeczy z intelektem jest prawdą empiryczną. Ponieważ podstawą mądrości jest prawda, to wskazane podejście empiryczne prowadzi do mądrości kształtowanej w sposób empiryczny. Studentom potrzebna jest mądrość użyteczna. Magistranci chcą poznawać świat (przede wszystkim napisać pracę magisterską), na podstawie hipotez weryfikowanych na drodze praktycznych badań. Oni chcą wyraźnie zdefiniować relacje przyczynowo-skutkowe:

„Mędrzec na widok chmur kładzie opończę, Upadek liści rychłą zimę wróży,

Gdy słońce zajdzie. Któż nie czeka nocy?

Przedwczesne burze droższy chleb zwiastują".

(William Szekspir, Ryszard III, s. 439) 
Zakres mądrości praktycznej wyznacza logika. Użyteczny obszar mądrości praktycznej niezbędny w przygotowaniu pracy magisterskiej określa logistyka. Promotor uczy zasad praktycznego postępowania metodycznego. Warte wykorzystania są ukształtowane przez wybitnych twórców metody organizacji pracy. Jan Sebastian Bach wskazywał na szczególne znaczenie w myśleniu muzycznym, porządku, spójności i proporcjonalności (Wolff 2011: 217). Realizacja pomysłów badawczych musi mieć precyzyjną konstrukcję podporządkowaną ciągłości i współzależności kolejnych etapów empirycznych. Cel pozostaje jasno określony - przygotowanie i obrona pracy dyplomowej.

Na podstawie przedstawionych dociekań można wykonać ostatni krok na drodze określenia mądrości w kontekście poznawania. Skoro poszukiwanie prawdy jest aktywnością intelektualną i wymaga zaangażowania podmiotu w poznawaniu świata, wówczas - Mądrość jest postaw ą podmi otu wobec rzec z y w i s t o ś c i skierowaną na odkrywanie prawdy empirycznej. Gdyby interesowała nas tylko mądrość użyteczna (empiryczna), to przeprowadzony wykład powinien dobiegać do końca. O mądrości w kontekście poznawania nic więcej nie należy mówić. Poza tym, tak rozumiana mądrość wystarcza studentom do osiągnięcia założonych celów kształcenia wyznaczonych dla seminariów magisterskich. Wiedza zdobywana podczas studiów staje się zbieżna z mądrością.

Powtórzmy raz jeszcze: mądrość jest postawą wobec świata. Tę postawę można inaczej określić oczekiwaniem. Na kogo czeka mędrzec? Odpowiedź brzmi jednoznacznie, on oczekuje na prawdę:

„wszystko jest prawdziwe, także czekanie

na prawdę".

(Paul Celan, Róża niczyja)

Prawda jest bowiem podstawą mądrości. Prawda jest stanem rzeczywistości. Prawdę można poznać, odkryć. Oczekuje się na nią. Prawda po prostu jest, niezależnie od postaw czy poglądów jakiejś społeczności. Natomiast mądrość jest umiejętnością poszukiwania prawdy, czy jak zapisał poeta „cierpliwością i oczekiwaniem". To nie poznający umysł wytwarza prawdę, to ona wyznacza jemu reguły postępowania.

\section{Kontekst rozumienia}

Immanuel Kant został wyrwany z metafizycznej drzemki przez Dawida Hume'a. Przed kilkoma laty po egzaminie magisterskim jedna $\mathrm{z}$ absolwentek wręczyła kartkę (przygotowaną w ramach akcji „Za kwiaty dziękujemy” prowadzonej w Uniwersytecie Łódzkim). Nastąpiło przebudzenie z drzemki dydaktycznej. Pani magister M. zapisała na czystej stronie kartki: 
„DZIĘKUJĘ:

- nie za wskazówki, jak napisać pracę magisterską;

- nie za prowadzenie zajęć i przekazywanie wiedzy;

- za cytat św. Augustyna (i moją 6 z historii kultury);

- za dobę spędzoną nad dziełami Tischnera, by wiedzieć, po co Bóg dał człowiekowi rozum".

Przywołane z przeszłości wydarzenie ukazuje inne oblicze mądrości. Nie wszystkim studentom wystarcza opanowanie zasad logistyki naukowej. Chcą oni przekroczyć granice postępowania praktycznego. Intryguje ich to, co jest zakryte przed wzrokiem empirycznego magistranta. W tej sytuacji należy podjąć trud dostrzegania sfery, która jest niewidoczna dla praktycznego poznawania. Stąd narzuca się mimowolnie odkrycie prawdy metafizycznej, równie ważnej dla absolwentów uniwersytetów jak wiedza praktyczna. Czyli mądrością jest postawa wobec rzeczywistości skierowana nie tylko na odkrywanie prawdy empirycznej. Fundament realnej rzeczywistości musi istnieć. Jednak jego umiejscowienie znajduje się poza obszarem poznawania empirycznego. Jawienie się zakrytego, tajemniczego, istotowego można dostrzec w prawdzie metafizycznej (Heidegger 2000: 18). Pragnienie jej odkrycia daje się nazwać rozumieniem. Jak zatem można dotrzeć do istoty rzeczywistości, która jawi się w postrzeganej prawdzie metafizycznie? Położenie istoty można porównać do punktu zbieżności w klasycznej perspektywie malarskiej. Ów punkt nie jest widoczny w ramach bezpośredniego doświadczenia, ale określa układ obrazu, jego logikę i kompozycję. Jeżeli uda się odnaleźć w zbiorach Muzeum Sztuki w Lodzi obraz Zbigniewa Pronaszko Portret żony z pajacykiem, to warto uważnie przyjrzeć się kompozycji dzieła (ryc. 1). Układ perspektywiczny obrazu został wyraźnie nakreślony. Przebieg krawędzi materialnych i położenie postaci podporządkowane są liniom perspektywy. Natomiast punkt organizujący perspektywę znajduje się poza obrazem. Odbiorca potrafi wskazać położenie tego punktu. Ostateczny efekt malarski wynika z jego umiejscowienia, ale pozostaje on niewidoczny.

Z ukrycia kieruje wrażeniami obserwatora. Jawność punktu zbieżności pojawia się wówczas, kiedy znane są zasady konstruowania klasycznej perspektywy.

Bywają także niedorzeczności, które w znaczący sposób wpływają na porządkowanie realnego świata. Św. Paweł Apostoł w pierwszym liście do Koryntian wskazał na ograniczoność mądrości empirycznej w poznaniu głupstwa, które oddziałuje na zorganizowanie rzeczywistości - „Tak też i ja przyszedłem do was, bracia, nie przybyłem, aby błyszcząc słowem i mądrością, głosić wam świadectwo Boże” (1 Kor. 2,1). „Gdzie jest mędrzec? Gdzie uczony? Gdzie badacz tego świata? Czyż nie uczynił Bóg mądrości świata głupstwem?” (1 Kor. 1,20). Obszar poza poznaniem mędrców jest sensowny. Jego przypadłością jest tylko to, że nie poddaje się procedurom weryfikacji empirycznej. Bycie poza logistyką nie oznacza pozbawienia sensu. O niedorzecznościach i głupstwach nie należy zawsze 


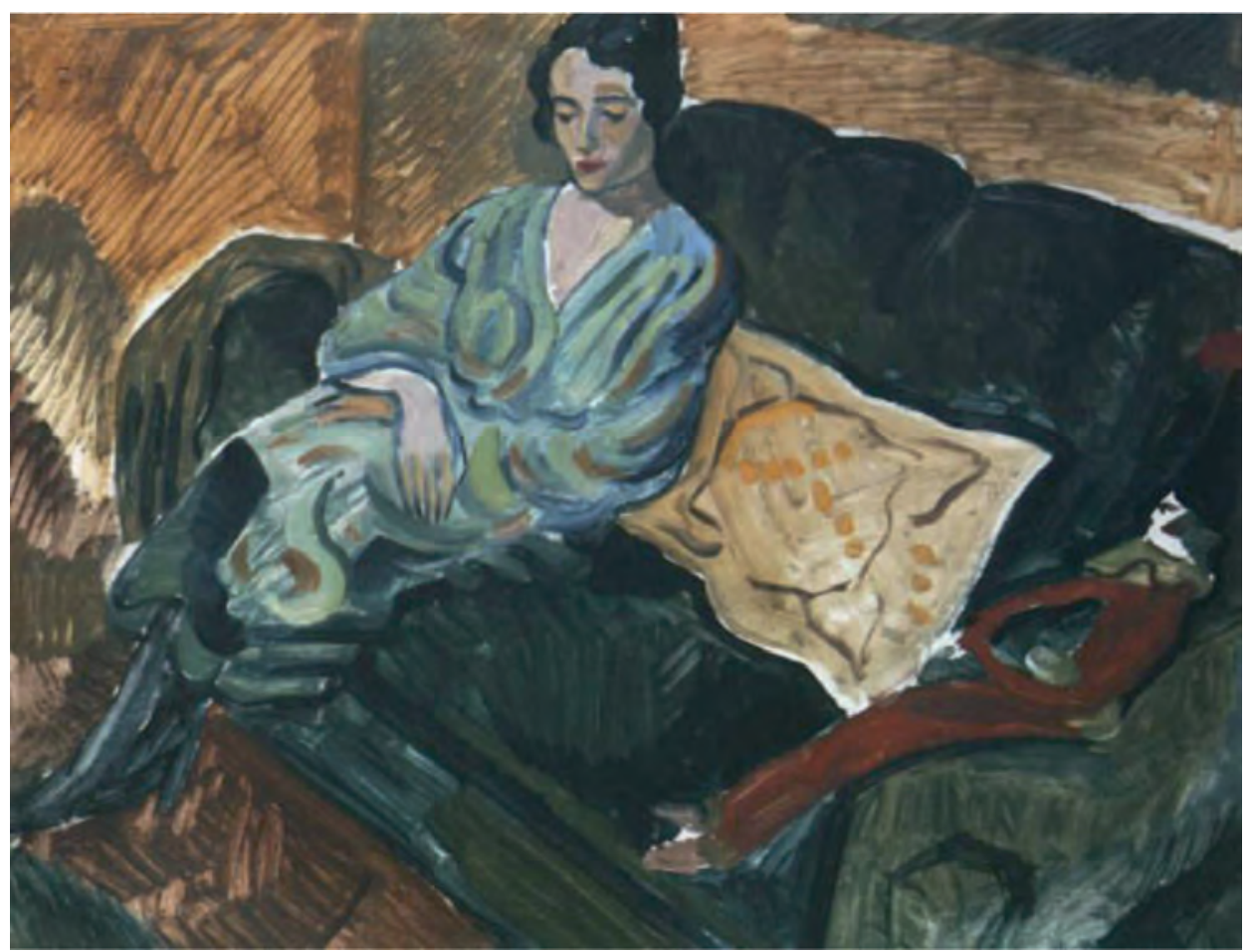

Ryc. 1. Zbigniew Pronaszko Portret żony z pajacykiem (ok. 1923)

- Muzeum Sztuki w Łodzi

Źródło: http://www.malarze.com (dostęp: 15.03.2013)

mówić, że są bezsensowne. Brak potwierdzenia empirycznego nie oznacza jednocześnie braku sensu. W taki oto sposób odsłania się istota prawdy metafizycznej - niedorzeczności logiczne mogą prowadzić do odkrycia sensu, czyli zrozumienia świata.

W skrajnych przypadkach uznawano prymat niedorzeczności nad prawdą empiryczną. Rozumienie świata powinno się opierać, zdaniem Tertuliana, na bezradności uczonych. Niemoc mędrców potwierdza wystarczająco pewność mądrości, która ma źródła poza doświadczeniem badawczym - „Syn człowieczy został ukrzyżowany; nie wstydzę się tego właśnie dlatego, że należy się tego wstydzić. Ale, to, że Syn Boży umarł, jest całkowicie wiarygodne, ponieważ jest to zupełnie nieprawdopodobne. To zaś, że pogrzebany zmartwychwstał, to jest pewne dlatego, że niemożliwe" (Swieżawski 2000: 333).

Jeszcze inne aspekty niedorzeczności czy też głupstw mogą zostać dostrzeżone w naukach ścisłych. Wykorzystuje się w nich pojęcia urojone, które pomagają w znacznym zakresie rozwikłać złożoną konstrukcję rzeczywistości. Takim przykładem są liczby zespolone, w których jednostka urojona odgrywa wiodącą rolę; 


$$
z=x+y i
$$

gdzie:

$z$ - liczba zespolona,

$x, y$ - liczby rzeczywiste,

$i$ - jednostka urojona: $i^{2}=(-1)$

Nie daje się zatem wyjaśnić świata wykorzystując tylko liczby rzeczywiste. Niedorzeczności są jak tlen dla życia na Ziemi. Same w sobie są głupstwem. Ale ich absurdalności są nieodzowne do ścisłego wyjaśniania empirycznej realności. Skrywana istotność odsłania zatem prawdę. Obszar istotowy determinuje realny świat poznawany empirycznie (ryc. 2).

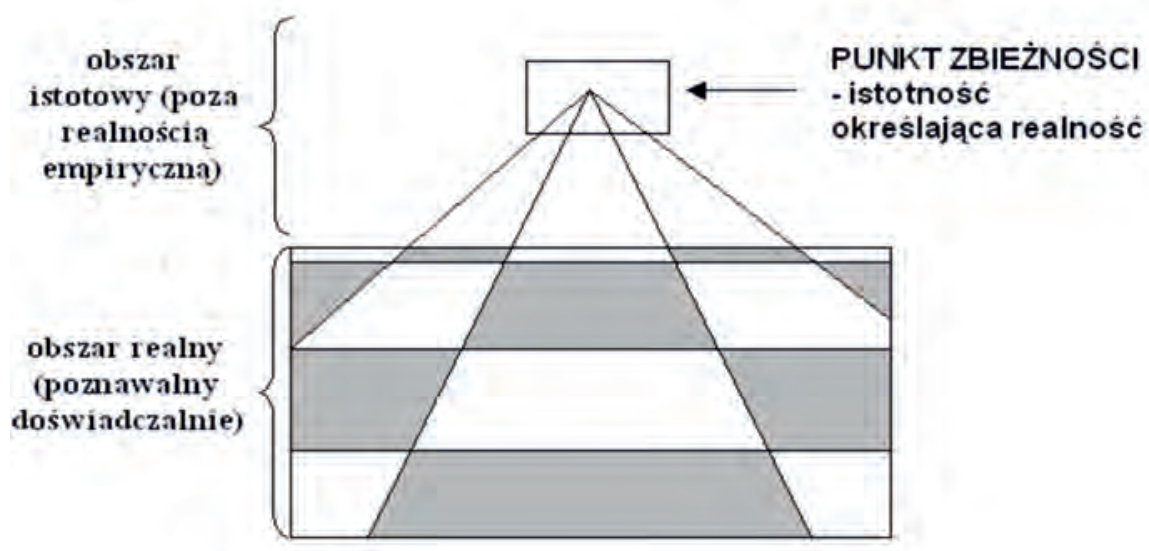

Ryc. 2. Uwarunkowanie realności poznawalnej empirycznie Źródło: opracowanie własne

Rozumienie świata polega na nieskończonym przemieszczaniu się na rozległych obszarach wiedzy i niewiedzy, le visible et l'invisible, sens et non-sens. Jednostka urojona jest bez wątpienia niedorzecznością w swej jednostkowości. Każdy nauczyciel matematyki postawi ocenę niedostateczną uczniowi, który w rezultacie podniesienia do kwadratu liczby ujemnej otrzyma liczbę ujemną. Dopiero w liczbie zespolonej nonsens staje się sensem. Niedorzeczności dostrzega się także w wielu innych przykładach. Należy jednak podkreślić, że niedorzeczności mają pomóc w odkrywaniu sensu. Czy można zwymiarować nieskończoność? Taki problem ma wielu fizyków uwikłanych w teorię pola kwantowego. Jednak teoria unifikacji pozwala skwantyfikować nieskończoność. Dowody w matematyce mają potwierdzać sensowność formułowanych twierdzeń. Bywają przypadki, że weryfikowana formuła musi zostać najpierw sprowadzona do niedorzeczności (reductio ad absurdum), aby osiągnąć wiarygodny wynik prowadzonej weryfikacji. 
Przedstawione w tej części rozważania pozwalają powrócić do sformułowanego wcześniej określenia mądrości. Wskazano tam, że mądrość jest postawą wobec rzeczywistości. Na tym etapie dociekań powinno się uzupełnić, że podstawą mądrości jest prawda empiryczna i prawda metafizyczna. Prawda empiryczna pozwala poznać świat. Natomiast prawda metafizyczna prowadzi do zrozumienia świata. Ujmując rzecz inaczej, można zaproponować zmienione brzmienie formuły mądrości - M ą d r o ść je s t p r a g n i e n i e m p r a w d y (empirycznej i metafizycznej). Należy wyraźnie zaznaczyć, że obie prawdy nie są sprzeczne. Nie można wykluczyć żadnej z nich w kształtowaniu mądrości. Jan Paweł II wyraźnie wskazał w encyklice FIDES et RATIO na relacje zachodzące pomiędzy prawdami o podobnej proweniencji - „Sobór Watykański I naucza zatem, że prawda poznana w drodze refleksji filozoficznej oraz prawda Objawienia ani nie są tożsame, ani też jedna nie czyni zbytecznej drugiej: Istnieje podwójny porządek poznania, różniący się nie tylko źródtem, ale i przedmiotem. Różni się źródtem, bo w pierwszym przypadku poznajemy za pomoca naturalnego rozumu, a w drugim za pomoca wiary. Różni się przedmiotem, bo oprócz prawdy, do której dojść może rozum naturalny, przedłożone nam sa również do wierzenia tajemnice zakryte w Bogu: nie można ich poznać bez Objawienia Bożego (Jan Paweł II, 2005: 1091). W większości przypadków myślący seminarzyści korzystają z dróg wiodących w stronę prawdy empirycznej. Natomiast dość rzadko podejmowany jest trud związany z dotarciem do prawdy metafizycznej. Niewątpliwie obie prawdy uszlachetniają wiedzę i umiejętności absolwentów uniwersytetów. Jednak prawda metafizyczna ma wyższą próbę szlachetności.

\section{Kontekst darowania}

Mądrość można potraktować jako dar, czyli talent, który zostaje nam przekazany w wieczyste użytkowanie. Na człowieka nałożony zostaje wówczas obowiązek dwojakiego rodzaju. Po pierwsze powinien on pomnożyć otrzymany talent. Następnie, pozostaje mu tylko obowiązek podzielenia się pomnożonym darem. Dalsze rozważania będą zatem prowadzić w obu wskazanych kierunkach.

W tym miejscu należy niewątpliwie zapytać - kto otrzymuje ów dar mądrości? Odpowiedź wynika z dotychczasowych ustaleń. Otóż darbiorcą mądrości może być każdy, kto pragnie prawdy. To jest podstawowy warunek, niezależnie od reprezentowanej postawy epistemologicznej, tzn. poszukiwania prawdy empirycznej bądź metafizycznej. Dar mądrości jest przygotowany dla tych, którzy odsłaniają prawdę w jej źródłowości. Pouczającą ilustracją omawianej kwestii jest fragment z Nowego Testamentu w thumaczeniu Zygmunta Kubiaka - „W tej chwili rozradował się w Duchu Świętym i rzekł: Wyznaję Tobie, Ojcze, Panie nieba i ziemi, że zakryłeś te sprawy przed mądrymi i przemyślnymi, a odkry- 
łeś je maluczkim" (Łk, 10; 21) W innych tłumaczeniach wskazuje się zazwyczaj na „wyróżnienie głupców”. Należy sądzić, że mówienie o głupcach jest daleko idącym uproszczeniem. Jako głupca powinno się traktować człowieka, który nie myśli i jest pozbawiony refleksyjnego oglądu świata.

W opisanej sytuacji, dar Objawienia otrzymali maluczcy, tzn. nie kształceni w (od)czytywaniu słów. Przede wszystkim nie czytywali oni słów, ponieważ nie nauczyli się formy ich zapisywania. Słowa bezkształtne były pozbawione treści, były obce maluczkim. Postrzegali oni świat takim jakim był, nie zaś na podstawie nazw słów. Bezpośrednie doświadczanie rzeczywistości miało większe znaczenie niż jej nazywanie. Tym samym, maluczcy nie byli kształceni w oznaczaniu rzeczywistości poprzez przypisywaniu jej właściwych słów. Jan Paweł II w FIDES et RATIO jednoznacznie wskazuje, że mądrość słów nie stanowi wystarczającego warunku, aby zrozumieć Słowo Mądrości (Jan Paweł II, 2005: 1107). Gdyby wziąć pod rozwagę słowo miłość. Treść słowa została określona. Miłość została słownie naznaczona. Ale odczytanie słowa miłość nie musi być tożsame ze zrozumieniem miłości. Stąd maluczki to człowiek nie kształcony w oznaczaniu słów. Natomiast nie musi on być bezmyślny. Interpretacja rzeczywistości bez pośrednictwa słów nie powinna być nazywana głupotą.

Wcześniej wskazano na dwojakie znaczenie daru. Otrzymujemy dar, dostajemy coś od kogoś. Aby jednak otrzymać dar, obdarowany powinien wykazać się postawą gotowości przyjęcia daru. Przyjmując nieco inny punkt widzenia, wzbogacony dar winien być komuś przekazany. Posiadacz mądrości także powinien wykazać się postawą otwartości na podzielenie się z innymi posiadanym dobrem. Warto ponownie powrócić do Nowego Testamentu w thumaczeniu Z. Kubiaka - „Komu wiele dano, od tego wiele będzie się wymagać, a komu powierzono wiele, od tego jeszcze więcej będzie się żądać" (Łk. 12; 48). Otrzymujący dar mądrości zostaje zobowiązany do jego pomnożenia. Bierność w tym zakresie jest marnotrawstwem, brakiem roztropności. Na obdarowanym spoczywa obowiązek wzbogacenia powierzonego daru. Pomnożony dar powinien zostać podzielony pomiędzy innych. To należy traktować jako jednoznaczne zobowiązanie. Posiadaczowi talentu wyznaczono zadanie. Dar mądrości, talent artysty są zobowiązaniem wobec społeczeństwa, w którym żyją i tworzą obdarowani. Zachowanie daru dla siebie byłoby oczywiście egoizmem i jednocześnie zmarnowaniem przekazanego talentu. Witold Lutosławski nie pozostawił wątpliwości w tej kwestii - otrzymany talent artysty jest jego zobowiązaniem wobec społeczeństwa. Wykorzystanie talentu nie jest tylko pracą. To jest misja (Skowron 2011).

W tym miejscu uzyskujemy dostateczne przesłanki do odpowiedzi na trzecie pytanie postawione we Wprowadzeniu - co jest miarą mądrości? Otóż, postawa pomnożenia i darowania mądrości jest miarą tejże mądrości. Miarą mądrości nie są posiadane jej zasoby. Miarą mądrości jest chęć jej darowania. Staję się 
bogatszy nie poprzez to co posiadam, ale przez to co chcę podarować innemu. Im więcej przekazuję mądrości, tym staję się bogatszy. Odpowiedź na wspomniane pytanie może przyjąć następującą postać - M i a r ą m ą dro ś c i je s t b o g ac two pomnożonegoi przekazane go daru.

W ostatniej części kontekstu darowania zostanie poddany analizie jeszcze jeden aspekt mądrości. Pragnienie prawdy wyłącznie dla jej posiadania określono już postępowaniem egoistycznym, pozbawionym roztropności (Wolicka 2008: 80-81). Zatem stwierdzenie, że mądrość bez uczynków jest bezużyteczna, ma głęboki sens. Mądrość cechuje aktywność, działanie w społeczeństwie. Z kolei warto uwzględnić przeciwny układ zależności, tzn. uczynki bez mądrości są ślepe. Wyraźnie widać relacje pomiędzy mądrością i działaniem. Jako podstawę mądrości wskazano prawdę. Natomiast istotną przesłankę działania stanowi dążenie do osiągnięcia celu zakładanego przez podmiot. Z takiego postępowania nie można wykluczyć pożądania zrealizowania celu. Przedstawione dociekania zbliżają nas do klasycznego pojęcia dobra analizowanego przez św. Tomasza z Akwinu i Edytę Stein (cz. I, zag. 5, art. 1). Dobrem według Edyty Stein jest to, „W czym dążenie znajduje swe wypełnienie” (1995: 332-334).

Mądrość stanowi połączenie prawdy i dobra. W prawdzie dominuje treść. Mamy bowiem do czynienia z poznawaniem świata i weryfikacją zgodności sądów o nim z rzeczywistością. Natomiast dobro to dążenie do celu, którym w rozważanym kontekście jest czynienie świata lepszym. Nie będzie nadużyciem zmodyfikowanie nieco klasycznego definiowania dobra. Otóż dobro powinno być rozumiane jako p o w i n n o ś ć w o b e c i n n e g o. Ta powinność może być pożądana, ponieważ ofiarowanie mojej mądrości innemu pozwala ofiarodawcy stawać się lepszym. Darujący mądrość uszlachetnia samego siebie.

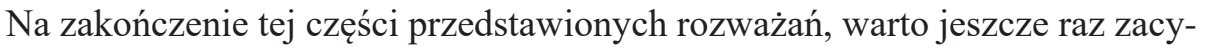
tować E. Stein: „Dążenie i dobro - tak samo poznanie i prawda - są co do znaczenia nie do pojęcia jedno bez drugiego, należą do siebie nierozdzielnie i żadne drugiego nie poprzedza" (1995: 337). Zatem określenie - M ą d r o ś ć j e s t d a $\mathbf{r} \mathbf{o}$ w a $\mathbf{n}$ i e m d o b r a, niech wystarczy za podsumowanie kontekstu darowania.

\section{Kontekst wydarzania}

Nadszedł właściwy moment, aby rozpatrzyć kolejny problem - gdzie mądrość się skrywa i jak ona się staje? Interesujący sposób doświadczania świata przedstawił Fernando Pessoa:

„Co ja myślę o różnych rzeczach?

Co sądzę o przyczynach i skutkach?

Jakim medytacjom o Bogu i duszy się oddałem,

I o stworzeniu świata? 
Nie wiem. Dla mnie myśleć o tym to zamknąć oczy

I nie myśleć. To zaciągnąć zasłony

Mego okna (ale ono nie ma zasłon)".

(Fernando Pessoa, Poezje zebrane Alberto Caeiro, s. 40)

W przedstawionym fragmencie poetyckim, mądrość nie skrywa się. Ona jest doświadczana bezpośrednio. Mądrość odsłania się przed wrażliwym obserwatorem i wydarza się w codzienności, w zwyczajnym doznaniu. Mądrości nie przeżywa się od święta, ona wędruje z nami zwykłymi ścieżkami w środowisku życia codziennego. Należy tylko zauważyć topniejący śnieg, czy opadające liście. Warto spojrzeć w twarz innego. Blask prawdy często odbija się od zwyczajnych rzeczy bądź zjawisk. Mądrość skrywa się w powszedniości. Czyli można skonstatować, że mą d r o ść wy d a r z a s i ę w c odzi e n n oś ci.

Aby rozum doświadczył mądrości trzeba otworzyć się na świat, warto wyjść na ulicę. Należy obudzić zmysły, aby autentycznie przeżyć rzeczywistość. W końcu „Kant-rozum jedzie do Ameryki, by odzyskać wzrok (...). Rozum, czy nadmiar rozumu powoduje ślepotę. Wiadomo, że człowiek widzi to, co wie: Ameryka ma nam zaś umożliwić widzenie tego, co widzimy..." (Lupa, b.r.w.: 23). Uważne patrzenie wokół pobudza myślenie. Spojrzenie innego pozwala także usłyszeć jego krzyk.

Mądrość potrzebuje wiedzy. Ale nadmiar rozumowości osłabia ostrość bezpośredniego dostrzegania świata. Aby dotrzeć do sedna mądrości potrzeba odrobiny szaleństwa. Zabrzmi to paradoksalnie - należy najpierw mądrość odrzucić, aby ponownie ją dostrzec. Myślenie pojęciami ogranicza czasami doznawanie realnych wrażeń. Wielu myśli pojęciem miłości, a jednak nie żyje miłością. Dlatego uczniowie usłyszeli od swojego Nauczyciela: „Tak więc nikt z was, kto nie oddziela się od wszystkiego, co posiada, nie może być Moim uczniem" (Łk. 14; 33). Z kolei Ludwig Wittgenstein zapisał w ostatnich fragmentach Traktatu logiczno-filozoficznego (6.54):

„Tezy moje wnoszą jasność przez to, że kto mnie rozumie, rozpozna je w końcu jako niedorzeczne; gdy przez nie - po nich - wyjdzie ponad nie. (Musi niejako odrzucić drabinę, uprzednio po niej się wspiąwszy.)

Musi te tezy przezwyciężyć, wtedy świat przedstawi mu się właściwie”.

Mądrości potrzebne jest szaleństwo i pożądanie. Zdobywanie mądrości powinno być spokojne i metodyczne, ale jej pragnienie musi być namiętne i gwałtowne. W dążeniu do mądrości badacz powinien dać ponieść się szaleństwu. To właśnie „szaleństwo" Krzyża otwiera drogę do źródeł prawdy empirycznej i metafizycznej (Jan Paweł II, 2005: 1108).

Mądrość nie jest przeznaczona dla ponurych ludzi pozbawionych marzeń. Mądrość nie jest w pełni dostępna dla tych, którzy uważają siebie za nieszczęśliwych. Wszak w Mądrości Syracydesa $(12,1)$ odnajdziemy myśl „Czyniąc dobro, 
wiedz, komu je czynić”. Nie każdemu dar mądrości bywa dostępny. Ponury niech się trapi o swoje nieszczęścia. Jemu mądrość przynosi tylko cierpienia. Natomiast epikurejczyk w mądrości odnajdzie radość i namiętność. Można obojętnie minąć kolejny zakręt na drodze. Ale trudno zrozumieć użalanie się nad sobą z powodu darowanej mądrości. Należy wyzbyć się posępnej mądrości. Wówczas lepiej popaść w głupotę. Przynajmniej ona dostarcza złudę dobrego samopoczucia jej posiadaczowi. Smętnym powinno się zabronić wstępu do krainy mądrości. Radość jest swoistą geometrią, która pozwala na przekroczenie bram Akademii (Dobrego Życia). Nijakość nie pozwala wstąpić ani do nieba, ani do piekła. Nędznymi są ci, „,o w świecie żyli nieżywotnie” (Dante Alighieri Boska Komedia - Piekło, Pieśń III).

Jeżeli mądrość wiedzie do zgryzoty, a nadmiar wiedzy pomnaża cierpienie (Koh 1,18$)$ to, dlaczego tak wielu o nią zapytuje i szuka jej źródeł? Cierpiący Hiob także pytał „Skąd, więc pochodzi mądrość i gdzie jest siedziba umiejętności?” (Hi 28, 20). Z kolei, pokutnik błaga „naucz mnie tajników mądrości!" (PS 51, 8). Trudno zatem zrozumieć postawę cierpiących. Męczy ich zgryzota, doznają wielu nieszczęść, a jeszcze pragną mądrości. Rozsądny człowiek w takich sytuacjach raczej unika boleści. Błagania o mądrość, która pomnaża troski nie można uznać za postępowanie racjonalne. W „marności nad marnościami” Kohelet dostrzega światło nadziei. Człowiek ma jednak szansę otrzymania mądrości, wiedzy i radości (Koh 2, 28). Z dążenia do mądrości płyną różnorakie pożytki - „mądrość przedłuża życie tego, kto ją posiada” (Koh 7, 12). W dalszych fragmentach rozważań o marności żywota wspomniano o radościach płynących z odkrywania mądrości - „Mądrość rozjaśnia twarz człowieka” (Koh 8,1). Treść Księgi Koheleta jest wyraźnie określona. Każdy zmierza do swego kresu i jako proch powróci do ziemi, skąd pochodzi. Należy zwrócić uwagę na sens ziemskiej wędrówki. Zarówno mędrzec, jak i głupiec podążają w tę samą stronę. Jednak sposób podróżowania ma istotne znaczenie, ponieważ to głupiec miota się w ciemności. Uważna lektura Księgi Koheleta i Księgi Hioba pozwala dostrzec drobne, ale niezmiernie istotne pouczenie. Otóż wszystko, co człowiek czyni powinno być dobre, radosne i przede wszystkim bezinteresowne. Jeżeli oczekuje nagrody za gromadzoną mądrość, to wówczas goni za wiatrem. Utrata posiadanych dóbr będzie wówczas należytą zapłatą. Mądrość jest wartością samą w sobie. Ona jest celem dla siebie i nie należy jej traktować jako narzędzia umożliwiającego zdobycie sławy i zaszczytów. Takie rozumienie mądrości jest oczywiście marnością i zazwyczaj prowadzi do upadku. Mądrość jest zatem bezinteresowna i nie oczekuje poklasku. Nie jest jednocześnie cierpieniem, ale radosnym obliczem mędrca. Nie przekonuje słyszane czasami sformułowanie, że mądrość jest cierpieniem. Św. Tomasz z Akwinu zapisał bowiem „(..) mądrość jako dar (...) pochodzi z miłości” (cz. 1-2, zag. 45, art. 2). Miłość oczywiście bywa tragiczna. Niemniej każdy poszukuje w miłości szczęścia. 
Nieszczęśliwy zawsze będzie się trwożyć. Dla niego radość tylko na chwilę przesłania marność bycia. Memento Mori niszczy radość mądrości. Nie pytajmy zatem, kiedy osiągniemy kres. To na pewno nastąpi. Popatrzmy raczej w twarz drugiego człowieka i odrzućmy głupie troski. Koniec drogi ma mniejsze znaczenie, liczy się sposób wędrowania z mądrością ku prawdzie.

\section{Podsumowanie}

W ostatnim fragmencie prezentowanego artykułu wypada rozliczyć się z podjętych zobowiązań. We Wprowadzeniu określono problem prowadzonych rozważań. Został on ujęty w formie trzech podstawowych pytań. Podjęta droga myślenia doprowadziła do sformułowania odpowiedzi, które są rozwiązaniem postawionego problemu. Rezultaty tej pracy przedstawiono w postaci następującego zestawienia:

- Mądrość jest postawą wobec świata;

- Mądrość jest pragnieniem prawdy i darowaniem dobra;

- Mądrość nie jest, ona się staje;

- Mądrość wydarza się w codzienności;

- Mądrość jest bezinteresowna, mądrość nie oczekuje poklasku;

- Mądrość nie jest cierpieniem, mądrość powinna dawać odrobinę przyjemności;

- W mądrości odkrywamy, jak sensownie żyć życie.

Jeszcze jedno pytanie na zakończenie - jak wysłowić mądrość? Odpowiedź nie jest skomplikowana. Mądrość powinno się wysłowić gorącym życiem. Mądrości nie można pokochać chłodno, rozsądnie, bez namiętności. Z kolei, Miłość ze swej natury jest namiętna, gwałtowna, całkowicie pochłania obie strony związku. Dlatego gorące życie powinno prowadzić do wysłowienia mądrości. Poszukiwacze mądrości powinni zostać jednak ostrzeżeni. Nie wolno popełnić błędu Józefa K. z Procesu Franza Kafki. Został on aresztowany, chociaż nie zrobił nic złego. Ale trzeba zapytać, co Józef K. zrobił dobrego. Jeżeli nic, to kara była zasłużona. Nam także, jeśli nie pomnożymy otrzymanych talentów zostanie odebrane to co ledwie posiadamy.

Jakiej nagrody możemy się spodziewać za życie mądrością? Zapewne otrzymamy biały kamień (Ap. 2; 17). I wówczas dojdziemy do kresu rozumienia świata.

\section{LITERATURA}

Biblia tysiaclecia, 1990, Wydawnictwo Pallottinum, Poznań-Warszawa.

Camus A., 1987, Dramaty, thum. W. Natanson, Wydawnictwo Literackie, Kraków.

Celan P., 2013, Psalm i inne wiersze, thum. R. Krynicki, Wydawnictwo a5, Kraków.

Dante Alighieri, 2015, Boska komedia, tłum. A. Świderska, Wydawnictwo Marek Derewiecki, Kęty.

Ewangelia wedtug św. Łukasza, 2004, w przekładzie Z. Kubiaka, Świat Książki, Warszawa. Heidegger M., 2000, Co zwie się myśleniem?, thum. J. Mizera, Wydawnictwo Naukowe PWN, Warszawa-Wrocław. 
Jan Paweł II, 2005, Encykliki Ojca Świętego, Wydawnictwo Znak, Kraków.

Kaczmarek S. (red.), 2012, Jak polubić pracę dyplomowa?, Wydawnictwo Uniwersytetu Łódzkiego, Łódź.

Lupa K., b.r.w., Immanuel Kant wedtug Thomasa Bernharda, Narodowy Instytut Audiowizualny, Warszawa.

Pessoa F., b.r.w., Poezje zebrane Alberto Caeiro, tłum. W. Charchalis, Czuły Barbarzyńca Press, Warszawa.

Skowron Z. (oprac.), 2011, Witold Lutosławski - O muzyce. Pisma i wypowiedzi, Tow. im. W. Lutosławskiego, Wydawnictwo Słowo/Obraz Terytoria, Gdańsk.

Stein E., 1995, Byt skończony a byt wieczny, tłum. I.J. Adamska, W drodze, Poznań.

Swieżawski S., 2000, Dzieje europejskiej filozofii klasycznej, Wydawnictwo Naukowe PWN, Warszawa-Wrocław.

Szekspir W., 2004, Dzieła wszystkie, t. VII, tłum. M. Słomczyński, Wydawnictwo Zielona Sowa, Kraków.

Św. Tomasz z Akwinu, 2004, Suma teologiczna, tłum. F.W. Bednarski, Wydawnictwo Antyk - Marcin Dybowski, Warszawa.

Wolff Ch., 2011, Johann Sebastian Bach, tłum. B. Świderska, LOKOMOBILA, Warszawa. Wolicka E., 2008, Postuga myślenia - Jana Pawła II idea uniwersytetu, [w:] Grzegorczyk A., Sójka J., Fenomen uniwersytetu, Wydawnictwo Naukowe UAM, Poznań.

Wittgenstein L., 2002, Tractatus logico-philosophicus, tłum. B. Wolniewicz, Wydawnictwo Naukowe PWN, Warszawa.

\section{WISDOM AND UNDERSTANDING THE WORLD}

Abstract Article presents author's reflections on dialogs and discussions which took place during master seminar for geography students leading by him. The main issue of the seminar was enumerated by the following questions:

- What is wisdom?

- Where one can find wisdom?

- What is the measure of wisdom?

Students shared with their professor different personal thoughts which allowed him to ponder his own opinion. The article is composed of three parts. The first one - introduction shows the background of presenting problem, the second part included different contexts of wisdom: i.e. cognition, understanding, granting, occurring. In the third part - the conclusion, Author proposes answers to the three questions stating as follows: wisdom is the need of truth, one can find it in everyday life, the measure of wisdom is the willingness to offer it to the other human being.

Keywords Wisdom, truth, knowledge, methaphisics.

Dr hab. Jacek Kaczmarek, prof. UŁ Instytut Geografii Miast i Turyzmu

Wydział Nauk Geograficznych

Uniwersytet Łódzki e-mail: jacek.kaczmarek@geo.uni.lodz.pl 